\title{
Forces of Altermodernization: Urban Social Movements and the New Urban Question in Contemporary Poland
}

\author{
Przemysław Pluciński ${ }^{1}$ iD
}

Published online: 8 June 2018

(C) The Author(s) 2018

\begin{abstract}
The article discusses contemporary Polish 'right to the city' movements and their potential for creating change, described here as the potential for 'alternative modernization', a term rooted in the alterglobalist movement. The waning of the latter's energy has fostered the emergence of local movements focused on protest and reform. In Poland, both an historical anti-urbanity and monologic patterns of regime transformation (the latter producing the 'anti-city') have become points of reference for urban movements and their demand for alternative patterns of modernization, called here altermodernization. The altermodernist model focuses, among other things, on discourses and praxis of decommodification, institutional reform and visions of a 'well-organized city'. The article is primarily a product of desk research and the author's own materials based on in-depth interviews collected in six Polish cities as well as participant observation and content analysis.
\end{abstract}

Keywords Right to the city - Urban social movements · Alternative modernization/altermodernization .

Commodification and decommodification · Post-socialism

\section{Introduction}

The history of societies is the history of urbanization. This paraphrase, albeit based on a deliberate exaggeration, brings into focus one of the key concepts and issues related

Przemysław Pluciński

plucin@amu.edu.pl

1 Institute of Sociology, Adam Mickiewicz University, Poznań, Poland to modern civilization. Urbanization processes set in motion centuries ago have been intensifying since the birth of capitalism and the industrial civilization, including in recent decades as we moved into the new millennium. According to the data collected by the United Nations Department of Economic and Social Affairs, the Earth is becoming a planet of cities and the world is now in the midst of an 'urban explosion' (Brenner 2013). This objective process has increased the importance of the socalled 'new urban question' (Merrifield 2014), even if it is manifested differently in every area of our urbanized planet due to particular historical, social, cultural and economic contexts. This urban boom is also a clear trend in Poland and throughout Central and Eastern Europe (Jacobsson 2016).

One of the results of this 'urban (r)evolution' is reinvigorated activism that has been visible for nearly a decade, in particular the revival of urban social movements and their key political demand, the right to the city (RTTC). While in many Western European countries these phenomena are a natural element of the public sphere, Poland and other countries in Central and Eastern Europe did not see their emergence until a decade ago. Polish urban movements are, therefore, forces for altermodernization. Their emergence in the arena of non-institutional politics was no accident; they have been raising questions and seeking alternatives for historical patterns at the precise point when the model of imitative capitalist re-modernization was being depleted. The very concept of altermodernization is stipulative: it refers to the alterglobalist slogan 'another world is possible' (Fischer and Ponniah 2003; George 2004; Scerri 2013) and transforms it. Responding to the challenges of imitative modernization, including neoliberal urbanism, 'different modernization' 
and particularly 'different urbanity' are seen by urban movement activists as possible and desirable.

There is also a certain similarity between the notion of altermodernization and Hardt and Negri's altermodernity (Hardt and Negri 2009, pp. 101-118), which has its roots in the Enlightenment, the (historical) search for socialistworker alternatives, and anti-colonial and anti-imperial struggles. The very concept of altermodernity, however, also has a very strong normative meaning, closely related to the communist teleology of revolution (Hardt and Negri 2009, pp. 325-375); hence, the search for a concept that does not reinforce such a teleology. Altermodernization, in turn, is closely linked to what Andy Merrfield has termed 'the new urban question' (Merrifield 2014).

Merrifield's concept represents an effort to transcend the historical perspective of Castells (1977). Merrifield traces the relationship between urban development, urban and social theory and political activism. He does so by examining phenomena associated with neoliberal urbanism, including 'accumulation by dispossession' (Harvey 2003), 'new enclosures' (Sevilla-Buitrago 2015) and 'parasitic urbanization' (Merrifield 2014), seeing them as a prerequisite for activist mobilization and a starting point for posing questions about the social resistance triggered by these processes.

The above-mentioned processes began to show themselves in Polish cities soon after the political transformations following the collapse of real socialism. Urban activism in Poland, however, has had to wrestle with a historical tradition of non-urbanity that stretches back to long before the post-socialist period. As a result, the new urban question in modern Poland has focused on identifying: (1) key urban problems, the sources of which are rooted in long- and short-term historical experience, and (2) those entities trying to address these problems by developing and attempting to implement concrete alternatives, i.e., a vision of the city that is as open, accessible and just as possible.

The first part of this article provides a reconstruction of the theoretical, empirical and historical contexts surrounding these issues, mostly based on desk research. It discusses the specificity of Polish urban movements and points to issues worth exploring. It also addresses the ambivalence of the Polish experience of urbanity from a long-term perspective (Kubicki 2016a, b) and from that of post-socialism (Jacobsson 2016), linking urban issues with the problem of imitative modernization. Consequently, it defines the crisis of current narratives and modernization practices and the search for alternatives through urban movements.

The second part is an attempt to confirm the altermodernist character of Polish RTTC movements on the basis of the author's own research, including interviews with activists involved in urban movements as well as on elements of content analysis and participant observation. Three key components of the altermodernization formula are discussed here: (1) the struggle for decommodification, (2) institutional reform through ownership disputes, and (3) the construction of the 'dream city' formula. The article ends with questions about the effectiveness of a long-haul strategy that may be adopted by institutions and 'becoming part of the system' as one possible means of implementing an altermodernizing model. The latter, however, are openended, and due to the complexity of the problem, a separate article should be devoted to these issues.

\section{Methodology of the Study}

The analysis is mostly based on in-depth interviews (IDI) interviews conducted in 2015-2017. These interviews were carried out with financial support from Adam Mickiewicz University's Institute of Sociology. In total, 26 interviews were carried out in seven Polish cities: Warsaw, Wrocław, the Tricity area (Gdańsk, Gdynia, Sopot), Gorzów, Łódź, Kraków and Poznań. The activists chosen for the study had to fit the criteria of (1) having been active for at least a year, and (2) being active in urban areas on the neighborhood, district and/or city level. During the process for selecting candidates to interview, the key movements and initiatives in a given city were first mapped and then contact was made with representatives of activist circles using the snowball technique.

Exactly half (13) of the respondents were women and half (13) were men. The vast majority of them were well educated and held university degrees. The interviewees represented a variety of occupations and professional skills (e.g., employees of third sector organizations, web developers, architects, academics, local administration employees, entrepreneurs). It was important to reach activists representing various spaces of engagement. The interviewees represented a total of 20 different organizations and initiatives, both formal and informal, sometimes acting through several organizations and/or initiatives simultaneously. The main spaces of their activity included spatial order, transport and bike activism, urban ecology, tenant activism, revitalization, social activation and organizing, participatory budgeting and urban democracy. In principle, all the activists dealt with more than one urban problem. Hence, in recalling the respondents' statements in the article, I focus on what can be defined as their primary area of activity. Many of the interviewees emphasized thateven when starting from activities at the neighborhood or district level — they consciously and deliberately operated, or at least aspired to operate, on the city level. 
The interviews focused on three main aspects: biographical (the role of their social and family background, the length and history of the interviewees public engagement), conceptual (focusing on the clarification of concepts, in this case on the meaning and interpretation of the right to the city category), and activist (the specificity of a particular interviewee's activities). The article contains only a small part of the data obtained, mainly related to the conceptual and activist aspects. All interviews were digitally recorded and transcribed (Kvale 2007).

The tools of participant observation were also used: this consisted primarily of direct participation in three out of five Congresses of Urban Movements, monitoring this work through access to the e-mail group discussions of its participants and also direct contacts with representatives of activist circles. The adopted perspective most closely resembles peripheral membership, where the researchers 'observe and interact closely with the people under study, and thereby establish identities as insiders, but they do not participate in those activities constituting the core of group membership' (Angrosino 2007, p. 55). The goals of participation were thus mainly exploratory in nature and were aimed at setting the context for further research.

The dangers associated with participant observation and the researcher's position, even if only partial, are fairly obvious. The very nature of academic interest in social movements, activism and civil society rarely allows for complete distance, and researchers more or less openly assume that-in accordance with Foucault's phrasing'society must be defended'. The perspective adopted here is closest to that of public sociology, in which research and sociology itself, in spite of being carried out while working alongside those being studied or their publics, do not merely become a transmission belt for their narrative and ideology. In other words, they are not transformed into 'a sort of intellectual vanguardism' (Burawoy 2004, p. 17).

\section{Urban Movements in Contemporary Poland}

As Paweł Kubicki suggests, 'Polish urban movements (...) are different in many aspects from those developing in the Western World', since 'after the transformation in Poland in 1989 the question of cities was relegated to a sidenote in mainstream political discourse' (Kubicki 2016b, pp. 246-247). This emerging divergence and this context of historical 'urbanless modernity' will be the point of reference for questions about the specificity of Polish urban movements.

While a thorough monographic study on Polish RTTC movements has yet to materialize, multiple works have been published that address some of the aspects of their functioning. The first studies into the genesis of urban trends within anarchist movements are now available, identifying the proto-urban character of their discourse and praxis in the late 1980s and early 1990s (Pluciński 2016). Research into the squatter and tenant movements in Poland (Piotrowski and Polanska 2016; Piotrowski 2016) is relatively well developed and is broadest in scope (AudyckaZandberg 2013; Polanska 2016a). Some authors have undertaken studies into the complex mutual relations between the anarchist, squatter and tenant movements from the perspective of alliance-building (Polanska and Piotrowski 2015). Here, the housing question has been at the forefront (Kostka and Czarnota 2017), along with demands for redistributive justice. The politics of urban protest have also been the subject of critical reflection (Kowalewski 2016).

Cultural studies on urban movements as 'new bourgeoisie movements' (Kubicki 2011) have been gaining more exposure within the framework of the so-called 'invented urbanity' perspective (Kubicki 2016b), identifying key city-making values shared in activist circles (Łuczak 2015) or interpreting the phenomenon as the rebirth of the intelligentsia ethos (Śpiewak 2015). Existing analyses also indicate the happening as the forebear of this phenomenon (Bielski 2010; Martela and Wojtaszczyk 2014).

Urban movements are also being researched from an institutional perspective, treated as important agents in both democratization and the democratic decision-making process. They are involved as actors in the (re)construction of urban public spheres (Kacperski and Kusiak 2012; Nowak and Plucinski 2011). They are sometimes perceived through a narrowed interpretative optics merely as part of the third sector and analyzed outside the category of a social movement (Sowada and Kotus 2015). Lastly, urban movements are treated as key policy-making actors that have sought to transcend the limitations of the politics of protest and consciously enter the system, questioning the rules of the game and introducing their own demands, praxis and values into the political system (Domaradzka 2015; Domaradzka and Wijkström 2016).

Even a preliminary literature review suggests that the category of urban social movement is an umbrella term, often concealing both formal and informal entities that vary greatly in their organization, ideology, social platform, praxis and strategies, as indicated by multiple researchers over the last years (Castells 1977, 1983; Fainstein and Fainstein 1974; Harvey 2012; Jacobsson 2016; Lowe 1986; Mayer 2009; Mayer et al. 2016; Marcuse 2009). This is mostly a consequence of the separation of analyses of urban movements from other types of social movements and even from the theory of social movements (Pickvance 2003, p. 104; Jacobsson 2016, p. 6).

Urban social movements can, therefore, be considered collective 'efforts aimed at challenging a present state of 
affairs by people with common purposes and solidarity in sustained interaction with elites, authorities and/or opponents, acknowledging that the repertoire of collective action will differ in different contexts and may range from symbolic resistance to overt protest (...) concerned with shaping the life in the city' (Jacobsson 2016, p. 7). In consequence, they 'share some characteristics in spite of their diversity: (1) they consider themselves urban, (2) they are locally based and territorially defined, and (3) they mobilize around the three major goals: collective consumption (or public infrastructure), cultural identity and political self-management' (Castells 1983, p. 328; Jacobsson 2016, p. 7).

Moreover, the acceptance of the demands of the RTTC as its driving ideology is a key (auto)definitional element for activists in urban social movements (Piotrowski and Lundstedt 2016; Pluciński 2014). In Poland, this phenomenon is clearly visible even though the understanding of it may vary and has become an empty signifier as defined by Laclau (Laclau 2007, pp. 36-46; Harvey 2012; Polanska 2016b; Pluciński 2013). This is unequivocally confirmed by interviews.

In principle, all my interlocutors, activists operating in utterly different fields (tenant activity on the one hand as well as the aesthetization of space on the other hand), invoked RTTC ideology as a reference point for their own. The RTTC is also a key element of the so-called 'Urban Theses', the proclamation of the Congress of Urban Movements and the main platform for urban social movements in Poland. These 'Urban Theses' and the demand for the 'right to the city' must be accepted by every candidate willing to join the Congress of Urban Movements. These characteristics allows to consider urban movements in Poland as RTTC movements.

Based on a 'hybrid' definition, Polish RTTC movements can be divided into two groups. One side is composed of (1) anarchist (2) tenant and (3) squatter movements, sometimes collectively called 'radical' urban movements (Piotrowski and Polanska 2016). The second group is (4) 'new bourgeoisie' movements, (5) urban third sector (with the presence of quasi-autonomous non-governmental organizations) and (6) local ad hoc initiatives, sometimes collectively called 'new urban movements' or 'middleclass movements' (Kubicki 2016b, pp. 239-246, 374; Pluciński 2015, p. 412). The analytical field can also include external actors, such as (7) political parties, particularly (but not exclusively) extra-parliamentary parties like 'Partia Zielonych' [The Green Party] or the social democratic 'Razem' [Together]. These parties, while not identifiable with social movements themselves, have been drawing on both personnel and ideologies or doctrines from them (Pluciński 2015, pp. 419-421). An attempt to develop closer links with urban movements, most likely with the aim of placing high-profile activists on their electoral lists, was made a few years ago by the Civic Platform party. However, their proposal for cooperation was rejected.

It is also worth attempting to define RTTC movements in Poland along a left-right axis. This issue is complex and deserves a wider study. At this point, one can only draw attention to the practices of labeling urban activism and attempts by activists at self-definition in an attempt to go beyond what has been ascribed to them. Urban movements in Poland are most often labeled as left-wing; however, this label has been structurally conditioned by two phenomena: the triumph of neoliberalism as the 'fuel' of transformation and the success of right-wing populism as a reaction to the crisis of the former.

The neoliberal narratives and practices introduced in Poland at the end of the 1980s, radical in themselves (Giddens 1994; Hardy 2009; Kowalik 2012a), soon evolved into dominant narratives, leading them to paradoxically become synonymous with 'centrism' and a new, post-socialist sense of normality, which sanctioned this shift in the political spectrum. In this context, all more or less genetically leftist projects, including those of social democracy, were gradually marginalized. This included a socially sensitive skepticism to capitalist re-modernization, especially privatization and reprivatization, raising the postulates of solidarity, and using the language of redistribution and the concept of public or common goods. In this post-transformational reality, they have been treated and are often still treated in Poland as 'radical', even cryptocommunist voices, if only because of their refusal to participate in the discursive worship of private property. It is a paradox that when the neoliberal project found itself in crisis, in Poland as well, the response was neither a leftist nor social democratic mobilization (currently the left has no parliamentary representation in Poland), but rather right-wing, nationalist populism.

Significantly, within the two dominant narratives (neoliberal and right-wing populism) there is a common space-a penchant for 'communizing' political opponents as a strategy for politically discrediting them (Lipiński 2016). Hence, there is a tendency to label urban movements as radical; they may be seen as radical, but only in a relational sense, within a closed and exclusionary political spectrum.

Urban movements by nature do not fit into any of the narratives referred to here. As pluralistic forces, drawing upon the notion of an open society, far from both free market orthodoxy and national ideologies, they have been subjected to stereotyping processes and discursively labeled 'urban leftism'. The so-called 'post-communist division', as one Polish sociologist described it some time ago (Grabowska 2004), still shapes Polish politics, including non-parliamentary politics. Perhaps that is why 
there are relatively few initiatives and urban movements originating in right-wing circles. The only strong milieu of this type seems to be the Kraków-based Jagiellonian Club. However, it is traditionally conservative and intellectual rather than populist-right-wing circle. At the same time, it acts not so much as a social movement, as an intellectual think tank, offering expert opinions rather than engaging in 'grass-roots activism'.

In addition to structural conditions, the self-definition of the activists themselves is also important. Here, the matter is equally complex. Although RTTC ideology can be described as leftist, we are presently observing a tendency to avoid unambiguous identification with such an ideological standpoint. My interlocutors likewise avoided this. While many of them, though not all, defined themselves as left-wing, they were hesitant to define their urban activity as leftist. In this respect, they emphasized not so much the apolitical nature of urban activity, as efforts (1) to preserve its objectivity, especially within the political duopoly of the Civic Platform and Law and Justice parties, and (2) to create an alternative 'ideological' platform, allowing one to work beyond the right-left trajectory, with the aim of not so much abolishing this division, as strategically surmounting it in order to solve specific urban problems. An expression of the belief invoked here is the idea of 'concrete narratives' (site-specific narratives) developed by Polish activists (Mergler et al. 2013, pp. 37-39). The idea cited here strongly shapes the political imagination of Polish activists.

\section{Neoliberal Urbanism and the Post-Socialist Perspective}

Apart from the constantly growing body of knowledge on Polish RTTC movements, there is an identifiable need for research into other, less prominent issues, such as the progressive institutionalization of movements and the dangers of 'oligarchization', including tensions between the formal and informal aspects of activism, political and methodological problems connected with the production of knowledge (Kostka and Czarnota 2017) and, finally, the need for intensified research into 'neoliberal urbanism' (Mayer et al. 2016).

The latter need to intensify research into 'neoliberal urbanism' appears to be the most pressing. Considering the fact that global capitalism remains a key motif in analyses of RTTC movements (Brenner 2013; Harvey 2012; Jacobsson 2016; Mayer et al. 2016; Polanska 2016b), and the scale (Smith 2010) of its effect and, therefore, the problems it generates on the national and local levels, there is a significant 'underrepresentation' of the neoliberal context in research into urban movements, especially in Polish academia. This appears to be a consequence of the strong involvement of the Polish intelligentsia (including sociologists) in the processes of systemic transformation, as well as the progressive neoliberalization of universities, and its contribution to theoretical and methodological conservatism (Kostka and Czarnota 2017).

The post-socialist perspective is currently one of the key analytical viewpoints on the issue of neoliberal transformation. Attempting to account for the specificity of experience and the current condition of Central Eastern European countries, the perspective assumes their historical similarity, in particular, the weakness the institutionalization of the welfare state, which has been a factor for securing the social contract and the institutionalization of conflict in the countries of Western Europe. The temporal context is also significant, defined by the issue of 'time compression', primarily observed in the sudden character of transformation. As stated by Jacobsson: 'while processes of privatization have of course taken place in the West as well, these adjustments in the urban patterns have been taking place much more gradually. Moreover, urban development in the West has been more strongly guided by public planning and the negative effects mitigated by public policies. The post-socialist countries, on the other hand, moved from central planning to a haphazard and chaotic urban development following a permissive laissez faire during the first 15 years of economic transformation' (Jacobsson 2016, p. 11).

The post-socialist perspective is not, however, without its limitations. Firstly, it implies a temptation to 'homogenize' experiences across countries and contexts. Secondly, it is connected with the danger of generating 'Otherness' along with assumptions about 'backwardness' and 'catching up' (Jacobsson 2016, p. 10). Thirdly, the historicity of post-socialism can be superficial and, therefore, its fixation on socialism as the undercurrent of present problems may be misleading. Lastly, with its focus on the past, this perspective leaves unproblematized the issue of overcoming the limitations it diagnoses. The two final points will be the key for further analysis.

The problem, therefore, is the issue of anti-urbanism as an element of Polish culture in the longue durée. From this perspective, modern urbanity as a phenomenon historically generated by emancipated city dwellers (burghers) is not natural to Polish experience (Leder 2014). It is also important to perceive the Polish transformation in stages: this includes both its initial phase, lasting around 15 years, and the perspective of the last decade, which began with Poland's accession to the EU. Paradoxically, post-accession Europeanization has led to a prevalent sense of depletion of the hitherto prevailing transformation logic and given birth to a demand for alternatives. 


\section{A Struggle with Modernity: Historical Non- Urbanity}

The integration of both perspectives - the look at historical non-urbanity and the current challenges of neoliberal urbanism in the face of a crisis of legitimization-allows for a better understanding of the phenomenon of urban activism in modern Poland. Polish RTTC movements appear to be a peculiar, autonomous force of altermodernization, attempting to cross the boundaries of historical experience.

In the history of urban civilization, Poland finds itself in a troublesome position. Rather than urbanity, a strong antiurbanism has been a trait of Polish culture since the beginning of the sixteenth century. Looking at the Polish urban question from the longue durée perspective can show peculiar 'moments of indetermination', or moments in time when-usually due to growing antagonisms or social struggles-attempts were made to significantly reconstruct the social-political order, and this came to define further progress. There were at least four moments of urbanity deficit: the Nihil Novi constitution of 1505; the struggle of city dwellers (burghers) for the inclusion of 'city laws' in the Constitution of May 3, 1791; the proletarian Revolution of 1905 in the Kingdom of Poland; and the present moment and the consequences of 'regime transformation' in 1989.

Between the thirteenth and fifteenth centuries, Poland was a middle-to-well-developed European state where both cities and city dwellers had no less opportunity for growth than in Western Europe. Developmental divergence occurred at the beginning of the sixteenth century, when the local gentry won the struggle for political domination with the king, cities and city dwellers, making the progentry Nihil Novi constitution of 1505 the symbol of its victory (Bogucka and Samsonowicz 1986). Based on its letter, Poland was transformed into a gentry democracy. The country was ruralized and the growth of cities slowed (Bogucka and Samsonowicz 1986; Ptaśnik 1949) along with the development of city dwellers and the modern public sphere (Sowa 2011). This led to the birth of an antiurban phobia (Bogucka and Samsonowicz 1986). As emphasized by Śmiechowski, even as late as the beginning of the twentieth century: "many authentic intellectuals believed that Poland should remain a rural country. They were afraid of Western civilization and its negative impact on a partitioned nation, and considered cities only as an addition to the country's agricultural landmark' (Śmiechowski 2014, p. 77).

The developmental consequences were no less than the Partitions of Poland and the nation's disappearance form the political map (Bogucka and Samsonowicz 1986, pp. 587-588). Shortly before that, city dwellers made an attempt at emancipation, symbolized by Jan Dekert and the so-called 'black procession', when peaceful citizens inspired by French Revolutionary ideas issued a memorial to the King, demanding economic and political rights (Ptaśnik 1949). These 'city laws' were initially included in the Constitution of May 3, 1791, albeit in a moderated version. Ultimately, however, they were suspended by the conservative, anti-royalist gentry during the Targowica Confederation (Bogucka and Samsonowicz 1986). The attempt at urban emancipation was a failure and Polish cities became outlying peripheries of the three powers that had taken part in the Partitions.

Another attempt to 'invent urbanity' was made during the Partitions of Poland, driven not by city dwellers, but by the proletariat in the Kingdom of Poland during the Revolution of 1905. Their struggle was an attempt to follow the example of the Paris Commune, an endeavor to reconfigure class relations and political subjectivity, with the democratization of cities and autonomy being key postulates. This put the Revolution of 1905 in stark contrast with previous uprisings led by the gentry (Śmiechowski 2014, p. 71). Struggling for urbanity, for the very experience of reclaiming the city, taking control of its space, and forming a new 'political body, counterpublic and a counterpublic sphere' (Smiechowski and Marzec 2016; Marzec 2013, 2016) were all key aspect of the Revolution of 1905. Unfortunately, this attempt was unsuccessful: the Revolution was 'quashed by the tsarist regime and interfractional violence' (Pobłocki 2011, p. 138).

The social and economic consequences of the partition of Poland and their links to the new urban problem cannot be discussed in short. It is usually pointed out that there were significant differences in the economic development between the Prussian partition and the Russian and AustroHungarian partitions, especially in terms of industrialization. Less often, if only for the sake of nurturing the memory of national liberation, different political strategies of resistance used against the partitioning powers are invoked. While in the Austro-Hungarian partition, and especially in the Russian one, the myth of armed uprisings and a model of patriotism based on shedding blood for the homeland was cultivated, in the Prussian partition, especially in Poznań and Greater Poland [Wielkopolska], the positivist ideas of Herbert Spencer were more popular, with their emphasis on the idea of 'organic work'. This consisted in combining the idea of "economic patriotism" with the those of socio-political self-organization and civic education in the spirit of social activism, social solidarity, and activism, though one unrelated to bloodshed or political and cultural resistance.

Putting aside assessments of this phenomenon and related stereotypes or self-stereotypes, it remains part of the political culture of the region to this day (Molik 2005). It 
has also provided a starting point for contemporary research on civic activity, including urban movements (Praczyk 2017). It is worth mentioning that during the 1 st Congress of Urban Movements, held in Poznań in 2011, representatives of activist circles from other cities recalled this Poznań ethos, thereby both reproducing a stereotype as well as expressing admiration for the civic involvement of the local community and seeking in it a source of historical continuity.

\section{A Struggle with Modernity: The Depletion of Imitative Modernization and the Problems of Neoliberal Urbanism}

The aforementioned struggles for urbanity all failed. We are now bearing witness to another fight for urbanity, one taking place between the imperatives of 'neoliberal capitalism' and attempts to transgress them to define the possibilities of 'alternative modernization'.

After the collapse of real socialism, Poland, like other countries in the region, became the arena of a grand neoliberal experiment (Aslund 2007; Sachs 2005) carried out in semi-peripheral conditions. It was carried out in Poland by means of a monological, top-down logic, above the heads of Polish society (Dunn 2004; Hardy 2009) and the movements that had actually made it possible (Ost 2006; Tittenbrun 1993). The Polish transition is a perfect example of imitative transformation (Kolasa-Nowak 2010; Sztompka 1999; Ziółkowski 1999) and attempts to build capitalism without capital. The fetish of private property became key and a progressive commodification of everyday life became the generative rule of the transformation. Among the main consequences of the new regime were rapidly increasing wage disparities, progressing social inequalities, rising poverty and growing problems with satisfying basic social needs (Kowalik 2012a, b), andfinally — mass unemployment, a major social fear and a tool for disciplining the working class (Urbański 2011, pp. 243-247). These problems were largely (but not exclusively) focused in cities, especially after the administrative reform in 1999, as a result of which, local governments were burdened with tasks connected with the acquisition of collective consumption goods, but were not provided with inadequate funding. The lack of coordinated urban policies also bears a mention as a contributing factor in the crisis.

The dissemination of a vulgar understanding of free market ideology followed by 'expendable people' and homo sovieticus narratives, along with a complete disregard for the politics of protest, gradually extinguished the embers of the post-Solidarity communal spirit. This led to the triumph of civic privatism, a defensive turn toward individualistic adjustment strategies (Jacobsson 2014). Sociologists critically observing these processes at the beginning of the twenty-first century proposed the thesis of a 'social non-movement' (Nowak and Nowosielski 2006), defining the social movements' vacant space. Many scientists also point towards the notable problem of incompetence and the poor quality of citizenship (Sztompka 1993; Raciborski 2011, p. 275), often considered to be the result of historical processes (Kaniowski 2003, pp. 92-95).

The post-accession reality is more complex. On one side, the neoliberal course has been maintained. On the other, the impulse to change the course of modernization cannot be ignored. Accession to the EU mitigated some of the pains of the first stage of transformation (e.g., very high unemployment). Increased mobility, including economic migration, became a factor contributing to shrinking cities (Łódź), while social learning processes became another effect of accession. Freedom of mobility popularized the experience of urbanity that was socially, architecturally and urbanistically different, giving birth to the need to reconstruct Polish cities. In the words of one activist:

Around ten years ago I started feeling that I'd like to be involved in changing cities. My work was largely traveling abroad, so whenever I returned to Łódź I would see the gap between a normally functioning reality and what we have here [female, Łódź, transportation and biking activist]

From an economic viewpoint, accession meant intra-EU distribution and structural funding on one side, with convenience for foreign investment capital penetrating the Polish market on the other (Grosse 2010, pp. 301-308). In consequence, certain characteristics of the urban transformations set in motion at the time can be identified (Kubicki 2016a, b, pp. 253-276). These characteristics defined the antithesis of a well-organized city and contributed to the RTTC movement's boom.

Firstly, the promise of an active, public housing policy remains unfulfilled. Research indicates that it was left to the market (Kubicki 2016a, b, p. 259), i.e., left to developers. As one of the key existential goods, housing underwent radical commodification (Kostka and Czarnota 2017). The housing issue was defined not as a 'public issue', but rather as a 'private trouble'. The question of haphazard reprivatization also cannot be ignored as it generates many systemic pathologies like the practice of tenement purging (Ciszewski and Nowak 2016).

Secondly, due to economic circumstances, like the relatively low purchasing power of city dwellers and increasing property prices in city centers as well as the progressive Europeanization of the market, the suburbs have become the dominant prospect (Kajdanek 2012), turning cities into places of transit between the urban 
workplace and suburban housing. The growing issue of urban transportation is a result of this perspective (Kubicki 2016a, b).

Thirdly, capital influx intensified spatial chaos. The neophyte-free market cult saw its vulgar urbanistic translation: the rejection of spatial planning and social control over the 'natural' market element (Jacobsson 2016; Springer 2013). The penetration of urban space by investment capital also resulted in sprawling gentrification (Pobłocki 2014), often barely concealed behind the fig leaf of revitalization (Witkowski 2013). As stated by an activist from the Tricity area when asked to describe her motivations:

There was that time at the beginning of the nineties. Investments were picking up speed... EU subsidies were beginning to show, along with various developer enterprises. It was at that time when Wrzeszcz started to change. New buildings were raised, either according to an incohesive spatial management plan or with no plan at all. Our activities were a form of protest against some of these investments [female, Gdańsk, neighborhood and district improvement activist]

Finally, the so-called white elephants became symbols of development (Kubicki 2016a, b, pp. 273-276). Meant to become the flywheels of local growth, these spectacular investments based on the belief in the ability to repeat to Bilbao effect were created at the cost of radical austerity: cuts in public funding. These overscaled investments and mega-events needed little time to become symbols of antisocial policy of growth, steeped in excessive grandiosity.

These processes reinforced the dominant monological, macrostructural and technocratic logic of transformation, projecting its characteristics on cities. On the other hand, the very same phenomena reached a critical mass and caused a reaction, leading both to protests and the birth of alternative projects. At the same time, antiglobalist energies have already been spent and social movements were (re)discovering localism (as glocalism). Moreover, new aspirations were stirring in Polish society, among them the need for agency:

I was thinking about which city to choose. My brother was a student in Poznań, a city I found very suiting, but also lacking that certain something I felt in Wrocław. After comparing growth indexes for both cities I saw that while Wrocław was below Poznań, it was also on the rise. Poznań was not struggling yet, it was still too early but... Anyway, perhaps I had a subconscious need to participate in urban growth. Funnily enough, that's exactly what I found [male, Wrocław, spatial order and city beautification activist]

The time described is, therefore, a period of interregnum, a moment when the old urban order is under question and new elements of the imaginary order are still being created.

\section{Forces of Altermodernization}

The urban initiatives and movements that started emerging in 2007-2008 in Poland's largest cities were at first isolated and unaware of the larger context. They were, however, quick to develop their own counter discourse, praxis and strategies as well as (re)construct local public spheres while facing the long tradition of non-urbanity, non-participation and the challenges of neoliberal urbanism. This change has been noted by Marta Smagacz-Poziemska: 'Where fifteen years ago (...) discussing the city as an enterprise was met with silent approval, today this language and its inherent ideology are met with resistance.' In Smagacz-Poziemska's view, urban movements are advocates for change, 'publicly dealing with the free market discourse and offering an alternative narrative, that of a collective city, filled not with great events and sports stadiums but with basic and universally accessible urban infrastructure' (Smagacz-Poziemska 2015, pp. 25).

The concept of altermodernization was introduced in the first part of this study. It focuses on 'different modernization' and 'different urbanity' that are seen as desirable. Values, narratives and a hitherto marginalized social praxis became key elements of this altermodernist model. The most important among these have been focused on: (1) decommodification, (2) institutional reform through the popularization of participation practices and ownership disputes and (3) the construction of the dream city (or wellorganized city) formula. All three of these elements of the altermodernist imagination are discussed in the following paragraphs.

\section{The Struggle for Decommodification}

The narrative of decommodification is clearly inspired by Esping-Andersen's seminal address (Esping-Andersen 1990), but the problem it poses takes on a new meaning in the urban context, becoming a narrative inspired by the struggle for both the classic understanding of public goods (Brenner et al. 2009; Corr 1999; Soja 2010) and for idea of the urban commons (Bakker 2007, pp. 430-455; Harvey 2012, pp. 67-88; Hardt and Negri 2009; Linebaugh 2014; Ostrom 1990). In this framework, the latter is becoming 
'the element of political praxis (...) emerging from social movements resisting the neoliberalization' (Enright, Rossi 2017).

In Polish cities, the struggle for the public good has become a struggle against the commoditization of housing along with caregiver and educational services, while activity focused around the idea of an urban commons can be found in the rebirth of cooperative ideas. Interestingly, rather than a subject of academic interest, the urban commons perspective is currently becoming a subject of experiments performed by urban movements. In Poland, however, these activities are of initiatory character:

I think these terms, the commons and public $\operatorname{good}(\mathrm{s})$, are often used interchangeably in Poland, while in my opinion they are far from identical. For modern city dwellers, public goods are an area of interest and activism. This fact is easy to observe in [a European city], where the entire science and art complex, built with large sums of money that put the city in debt, was designed by [a starchitect's name]. These jewels of architecture symbolize the power of the ruling bourgeoisie, proclaiming its power, magnificence, good and beauty. At the same time, these buildings fall within the category of a public good: museums, public event halls, etc. It's paradoxical to me that Polish movements on the political left, which often fight for the public good, are considered an extremist, leftist fad by many Poles. The world's bourgeoisie has evolved to appreciate the fact that there can be no high living standards without quality public goods. On the other hand, I consider the common good a self-explanatory element of a communist ideology. It is not the same as public property, which exists right next to private property, because the common good is a type of a commune where we, employees, own everything [male, Kraków, cooperative and tenants movement' activist]

While the tenant movements are not the only social actors active in the field, their activists were the first to demand decommodification. The 'Housing is a Right, Not a Commodity!' ('Mieszkanie prawem, nie towarem!') national campaign, open to non-tenant actors and bringing together movements and activists, stands as its symbol. The activities of tenant movements have long been reactive and defensive in nature, focused on resistance against the negative effects of privatization and the commoditization of housing, violation of tenant rights (much easier in a vulgarly commercialized market), tenement purging processes, and projects attempting to ghettoize the poor, symbolized by the construction of living quarters for the poor from shipping containers (called 'social containers'). When asked to identify the key tools of their movement, activists list legal counsel (available free of charge or below market prices) and at least partially decommodified tools of social solidarity (mutual support, both materials and non-material and mutual participation in court proceedings), and eventually the blocking of evictions.

A gradual change can also be observed within the protest repertoire. Coming to the fore are non-reactive strategies, with more evident links to social supervision. There has been increasing pressure by tenant movements on local governments in recent years, manifested in participation in housing round table discussions (Warsaw, Kraków, Poznań) and diligent spokespersons defending public interests at City Council meetings. Having already taken root in the public consciousness, this pressure, coupled with the housing question, did not go unnoticed. Local governments, albeit not yet on a mass scale, have been declaring a return to an active and public housing policy, mostly focused on providing more social housing options. It has become clear that years of activity by 'secret agent' (Merrifield 2014, pp. 119-120) have been slowly, but surely transforming housing policy in cities like Poznań and Warsaw. In the latter, more than 300 billion zloty has been promised to a new housing programme, Housing 2030 .

Numerous social movements for the public good are also subjects of decommodification struggles and the Kraków RTTC movement stands as an archetypal example. Rooted in the local resistance movement against social funding cutbacks impacting social care and education, which resulted in school closures, the movement grew with numerous smaller, informal social and parent initiatives. Actions by activists led to a significant reduction in the number of educational facilities earmarked for liquidation.

I think it's underappreciated (...), but it's still a big success to limit cutbacks like this. Over two seasons of cutbacks several dozen schools were to be either shut down or become private education entities and only two or three schools were actually closed. We were able to save the rest [male, Kraków, cooperative and local NGO activist]

The initiative later gave birth to 'Kraków Przeciwko Igrzyskom' ['Kraków against the Games'], an informal body connected with the 'Inicjatywa Prawo Do Miasta' ['Right to the City Initiative']. Its main objective was to block the projected Winter Olympic Games in Kraków and Zakopane in reaction to the anticipated high costs of the mega-event, negative consequences for the city's budget, and the likelihood of draconian cutbacks in social funding (Piotrowski and Lundstedt 2016, pp. 205-207). A similar initiative, namely 'Chleba zamiast Igrzysk' ['Bread instead of Games'], took place in Poznań.

The restitution of cooperative ideas and praxis is another decommodification impulse. Though it is perhaps 
premature, it could be called a new wave, referring to preWW1 traditions of Polish cooperatives, including the ideas of Edward Abramowski and Konstanty Krzeczkowski, also rooted in the context of the social economy. As a part of the modern urban commons narrative, the cooperative trend is developing in three cities: Warsaw, Kraków and Poznań. Exemplary cooperative initiatives include 'Ogniwo' in Kraków and 'Zemsta' in Poznań, both strongly connected with local RTTC movements:

'Ogniwo' was started by members of the Right to the City Initiative. It started out as an idea for a housing cooperative after someone told us about micro cooperatives, but we realized we couldn't afford to run one. We also felt like we needed a base. The movement was strong and energetic enough that it needed some kind of anchorage point, and we knew we would have to create it ourselves [male, Kraków, cooperative and local NGO activist]

The importance of the activities carried out by urban cooperatives cannot be overstated. They became local social centers, animating debates, activating the public, and functioning as civic coffee shops, bookstores and-indirectly—a publishing house ('Zemsta'; 'Bractwo Trojka'). However, urban cooperation is still in a blossoming phase, and it is limited to service sectors strongly connected with an urban lifestyle. One cannot overlook, however, the transformative potential of this type of activism, especially since it connects with the nineteenth-century ethos of organic work (Janowski 2004; Praczyk 2017), as a form of resistance praxis against the logic of neoliberal urbanism.

The issue of participatory budgeting (PB) could be a separate analytical subject in studies on the struggle for decommodification, especially given that more than a decade has passed since the postulates of PB first emerged in Poland among social movements, mostly urbanized anarchists (Czapka 2010, pp. 5-18; Górski 2007, pp. 64-113). They were swiftly seized upon, popularized and instrumentalized by local governments, becoming a strong trend manifesting today mostly in the form of plebiscites. The socializing potential of PB has had scant effect on Polish reality. Analyses indicate that civic budgets in Poland do not function according to its principles, and while they serve multiple purposes (facilitating communication between local governments and citizens, meeting particular needs and more), their influence on key decisions-both politically and economically-remains limited (Gerwin 2013a; Matczak et al. 2015).

\section{Institutional Reform: From the Right to the City to Ownership Disputes}

Analyses of RTTC movements, particularly pertaining to institutional issues, are mostly focused around political problems, the understanding of which varies to a great degree. Within this framework, RTTC movements are treated as vital agents of democratization. The case of Poland serves to confirm this argument. Urban activism must by necessity fit within the narrative of the restitution of civil society and the public sphere in accordance with the phrase 'We have (re)built democracy, now let us raise democrats'. In this sense, RTTC movements are subjects of emancipation from the perspective of the longue durée (Kubicki 2016a, b), a rekindling factor in the seemingly lost struggle for urbanity (Gorzelak 2013). Urban movements activate social learning processes, constructing a framework for urban democracy (Mergler 2011, pp. 163-182) and playing a significant role in the reconstruction of the political landscape. Research shows a cohesive pattern in the understanding of the right to the city as a bundle of rights, with the deeply democratic postulate of promoting participation in decision-making processes and urban democracy as its core. To quote just a few interviews:

First of all-let residents make decisions or participate in the decision-making process. [female, Łódź, transportation and bike activist]

The right to the city can be a way to democratize democracy. Urban movements, which arose at one point as a theory, were a means to democratize representative or parliamentary, bourgeois democracy. [male, Kraków, cooperative and tenants movement' activist]

The right to decide, to influence what happens in the city. [male, Warsaw, urban democracy activist]

The right to make decisions about common space understood broadly, both as a literal space outside your window and the public sphere. [female, Kraków, public education and social care activist]

Other answers profiled the demands of the RTTC differently, with stronger emphasis on the lens of decommodification:

In my understanding the right to the city as a city that is not managed like a business. It is not just an infrastructure meant to earn a profit and generate as few costs as possible, but an organism that should serve people's needs. [male, Warsaw, anarchist and tenant movement' activist] 
Codetermination, co-creation and equal access to all goods. [female, Warsaw, spatial order, transportations and biking, tenants movement' activist]

The naturally recurring context of the struggle for decommodification implies the need for a discussion centered on the issue of ownership. The RTTC movements' well-developed analytical framework of political function(s) should, therefore, be supplemented with another often overlooked institutional aspect, namely the viewpoint of ownership (Baranowski 2010-2011; Kowalik 2010-2011; Tittenbrun 2014).

A key aspect of property analyses lies in their substantial or relational understanding. In the former case, as illustrated in the theoretical and doctrinal work of various liberal and conservative-liberal schools (Friedman 1982; Nozick 2001; Rothbard 1978), we are dealing with property seen as absolute or 'natural' (natural rights discourse), which in practice is ideologically fetishized or at least 'lyrically' apotheosized. Property here is defined as a relation between people and things, objects of ownership that subsequently define social relations. Moreover, property substantively conceived is often associated with only one of its forms: private property (Bollier 2014). This, in turn, connected with the doctrinal belief in the absolute superiority of capitalism and the free market (often seen as synonymous) over other forms of organization of the socioeconomic sphere. As a rule, the core of the argument lies in belief in the greater economic efficiency of private property (Tittenbrun 1996).

From a relational perspective, ownership is a relation between subjects mediated by a relation to an object or thing. The relational perspective, in turn, treats ownership as a changing, historical institution, based not on a substantive belief in its roots in natural rights, but rather emphasizing its social, contractual character (Bollier 2014; Linebaugh 2014). The relational perspective assumes multiple forms of ownership: private property, personal property and different types of co-ownership: public property (public goods) or social property (common goods, cooperatives). Relational analysis also better reflects the analysis of the phenomenon of free goods. No doctrinal assumptions exist on the superiority of private property over any other form of ownership relations, particularly in the context of efficiency.

From the perspective of ownership relations, the Polish political transformation should be treated as a capitalist revolution or re-modernization prepared by economic radicals fascinated with Milton Friedman's orthodox monetarism or with the radical liberalism of the Austrian school (Kowalik 2012a, pp. 15, 22-23). Public discourse became dominated by a synonymous understanding of property and private property. Paradoxically, this attachment to private property has become common in Polish society in spite of research showing a relatively widely shared egalitarianism and lack of acceptance for excessive inequality. The causal link between the latter and its cause-the vulgar version of capitalism based on fetishized private property, naturally commodifying and reinforcing inequality - has been lost, at least at the level of social consciousness (Podemski 2009).

A hypothetical reason for this can be proposed: the hypothesis of a post-communist backlash. The formal attachment to private property shared even by people entirely devoid of such property is the answer to the unfulfilled promise of real socialist collectivization. The force of this backlash can be seen in public discourse, particularly now, as the Polish People's Republic seems to be living a life after death. Nearly three decades after the end of real socialism the dominant conservative-national narrative is based on settling scores from the 'real socialist' era. Within this narrative, any voices critical of capitalist modernization, like the rhetoric of decommodification, collectivization or community narratives are treated as communism from beyond the grave, with the strategy of 'communization' of political opponents (Lipiński 2016) becoming an effective and dominant political tool in the Polish public sphere. Moreover, not-too-subtle accusations and epithets concerning urban leftism are far from rare in the conservative-national media. An atmosphere of moral panic is created: 'Urban acivists want to kill us?' (Zboralski 2016). Urban cooperatives like 'Zemsta' in Poznań and 'Ogniwo' in Kraków have been the object of physical attacks by right-wing extremists: windows were broken, property destroyed and harmful substances sprayed inside their premises.

In search of a broader context to explain the aforementioned phenomena, one could call on Wallerstein's thesis, wherein the axioms of the free market, including the vulgar organization of ownership relations, are forced on weak peripheral and semi-peripheral actors, who take them as their own, unaware that even the capitalist center is not orthodoxically competition-based and readily abuses its right to change the rules of the game (Wallerstein 2004). The specificity of Polish semi-peripheral capitalism is a consequence of processes set in motion and reinforced over the last five centuries, its historical anti-urbanism and the paresis of city dwellers being inherent components of these processes. The postulates and praxis of urban social movements are a part of the struggle for an institutionally different modernity. The relativization of ownership relations is a vital element of this:

Ownership in itself is a contract (...) I don't see property rights as sacrosanct. They are subject to limitations which are a matter for debate. I 
understand that ownership rights are sacrosanct for many people in Poland. After a long period of nonexistence, the property rights pendulum has now swung the other way. [female, Łódź, transportation and biking activist]

The city is a focusing lens for the structural stresses of capitalism and the problems of its narrative. Key among them-the axiom of private property's superiority over public property, with a strong representation in the managerial logic of administration. Its weaknesses show themselves in at least two instances. The logic of profitseeking usually leads to an imbalance, the coexistence of numerous vacant flats and unmet housing needs. These situations legitimize people's wariness of capitalist rationality (Polyak 2013). Polish RTTC movements, inspired by the Right to the City-NYC Alliance's methodology, have attempted to demystify the phenomenon of social housing shortages by finding several hundred vacant flats throughout Poznań (Kostka and Czarnota 2017).

Squatter practices are another front in the struggle. Squatters have a strong argument that vacant flats are wasteful from the perspective of economic efficiency, providing an example of irrational allocation and underutilization of factors of production. The squatter as its new user restores to the flat its economic raison d'etre. In the words of a non-radical activist:

As a concept, ownership rights are incompatible with the times we live in. I know that radical changes have been introduced, I think in Brazil, where unused properties, especially buildings, can be forfeited. It's a way to eliminate vacant flats. [female, Łódź, transportation and biking activist]

Disputes about the shape of ownership relations are present throughout RTTC activism, mostly in tenant movements. Attempts to reposition housing as a public good and the appreciation of this are the main subjects of this activism, as stated in extenso below:

There are two opposite positions on the issue of housing. The first one tells us housing must be privatized, and anyone who is not yet a homeowner should do their utmost to become one (...), to take out a loan for the next few decades. The second trend claims the opposite. The [...] Association has always been against the privatization of communal housing (...). We see this as destruction of communal resources. We are for social and cooperative housing based not on commercial property, but on access to housing that doesn't necessarily have to be property. If people want to take out loans and purchase apartments from developers, it's their choice. The problem is that there is a shortage of social housing. A huge majority of loans are taken out not because people prefer to own apartments, but because they have no alternatives. According to current urban policy, social housing is intended for the poor. We want every social group to have access to housing. [male, Warsaw, anarchist and tenant movement' activist]

The aforementioned narrative in no way fits the claimant or homo sovieticus stereotypes popular in liberal discourses. It is rather a demand for normalization of the housing market and a call for the government to implement actions and obligations expected of it. 'Red Vienna', a term customarily used to refer to the period of far-reaching social democratic reforms in that city in 1918-1934, among which was a well-developed system of social and health services and public housing (Weihsmann 2001), is both the likely background and dream behind this phenomenon.

\section{Dream Cities}

As subjects of progress, not reaction, social movements by definition design the future, attempting to go beyond the horizon of limitations often determined by the past. Movements struggle with the 'concrete utopia' that is the object of their fight and construct a normative moment. In the past, this took the form of different, often quasi-utopian visions of a 'well-organized society'. In the case of RTTC movements, these visions focus on well-organized cities or dream cities. Yet, a working definition of their antithesis is easier to formulate, as urban growth in the twentieth century was based on the intimate relation between capitalism and urban modernism (with full awareness of the ambivalence of the modernist movement). Its symbols are not limited to the opportunistic genius of le Corbusier, an architect who would serve anyone to implement his ideas, but stretch to Robert Moses' sheer scale and Frank Lloyd Wright's anti-urban idée fixe (Graham 2016).

The return to urbanity in the perspective of urban movements is a turn towards the down-to-earth, communal, socialized cities of Jane Jacobs (1992), Jan Gehl (2010) or Leon Krier (2009). Ideas created by these three visionaries were points of reference for many urban movements and initiatives. Their influence in Poland, Jan Gehl's in particular (Gemzoe and Zakowska 2013), is also very strong, probably due to its immanent humanism and open break with technocratic urban visions. Also of note is the fact that urbanists and architects are often active members of urban movements. The fact that urbanist Krzysztof Nawratek's influential book City as a Political Idea was another important impulse for Polish RTTC movements is certainly not without significance. First published in Polish (2008), 
the book had to wait a few years for its translation into English (2011).

What additional elements—other than a decommodified, egalitarian city-constitute an altermodernist formula? It can be reconstructed by following the urban discourse within the local and regional public sphere. Yet the body of (self)knowledge generated by urban movements is continuously growing. And as it grows, it more and more often transcends the traditional division between academia and activism. This can be observed both in the movements' own publications and in publications about the movements, although this distinction itself is also becoming increasingly questioned. Publications constitutive of urban discourses seem to prove this point well (Bukowiecki et al. 2014; Mergler et al. 2013).

Analysis in toto remains impossible, but the urban vision from the pages of Miasta [Cities] magazine can provide a representative example. A national, opinion-forming periodical created by actors connected with urban NGOs as well as urban activists, Cities, holds a special position as an official, professionally published entity, not an underground brochure, samizdat or zine. The main purpose of the magazine is to move beyond the boundaries of a wellknown environment and send a message to non-activist audiences. The rhetoric is positive in nature and not based on frontal criticism of a 'city for cars', but rather on the affirmation of alternatives in the form of a 'city for people' narrative. The transition from a 'resistance identity' to a 'project identity' (Castells 2010, p. 8) is visible.

Each issue has a lead subject and, while early on, the magazine took up problems connected with tenancy (Haratyk and Wnek 2012; Manifest 2012; Urbański 2012), collectivization and urban public and common goods (Erbel and Ratajczak 2013) and kept activism in focus, subsequent issues were increasingly concerned with the perspective of local governments, the needs of which (as a potential client) started driving the magazine's profile. For sometime now more space has been given to urban cultural policies in their institutional understanding, though plenty of space remains devoted to (urban) art in public spaces.

The issues of urbanism (Buczek 2013) and sustainable transportation (Polakowski 2016) are also strongly represented, with particular importance attached to sustainable growth. The appreciation of neglected perspectives is key, including that of the pedestrian (Pelanosa 2016; Rumińska 2013), the cyclist (Puchalski 2013), and the commuter. A well-organized city is, therefore, a city that leaves the automobile monoculture (Gerwin 2013b) behind.

Public spaces and practices for reclaiming them after years of privatization excess are an important element of the narrative, along with spatial conflicts and tools for solving them. Much reading space is also devoted to widely discussed problems concerning participation, its merits and traps, and the meandering path of urban democracy (Penalosa and Lanski 2013; Gerwin 2013a, 2015; Prykowski 2013; Świderski 2016). Urban entrepreneurship is another important problem discussed, particularly the question of the responsibility of businesses to the local community (Litorowicz 2014). Finally, a well-organized city is also filled with people who are not welcome, condemned to invisibility and defined as faulty users, including migrants (Hebanowski 2015), seniors (Szczerba 2013), children (Brzozowska-Brywczyńska 2013), and disabled or ill persons (Erbel 2016).

All the aforementioned motifs seem rather obvious from the perspective of an enlightened debate about late modernity and its logic of inclusion, but Cities also presents multiple issues dwellers have yet to face: megatrends and future challenges prognosticated by international agencies like World Health Organization (urban demographic transformation) or the United Nations (the HABITAT program being of particular prominence). These problems are also connected with the challenges of a technicized life, energy challenges in the urban context, or, more broadly, resource challenges, smart cities, or the sharing economy. These discussions are often translations of highly professional expert policies into the vernacular, motivated by the need to disseminate knowledge (Dorda 2015; Jaworski 2016; Litorowicz 2014).

In the altermodernist context, Cities magazine remains relevant for no less than three reasons. Firstly, it functions as a forum for the exchange of beliefs, traditionally iterating the logic of a liberal medium open to discussion and a public churning of opinions, ideologies and viewpoints. The magazine activates social learning processes, constituting an ideological vanguard of change. Secondly, Cities is a toolbox serving as an important means for the exchange of knowledge concerning praxis and urban knowhow (Billert 2012; Gerwin 2013a, 2015; Zerka 2013). Thirdly and finally, the magazine serves as a time machine, a platform for highlighting urban trends, capable of taking the reader on a discursive journey to 'cities of the future' in accordance with the principle that the 'future is now' (Mergler 2013b; Litorowicz 2014).

Urban discourses, including Cities, can be viewed from yet another perspective: while carving out a model for the city, they simultaneously propose a normative model for the city-dweller. They, therefore, positively value the category of urbanite or townie. By establishing such a positive view on urbanity, they radically break from a long, antiurban tradition within Polish culture.

When recalling the problem of a well-organized city, a spontaneous question presents itself: are these visions imitative or adaptive? While the imitative nature of monological, transformative modernization is unquestionable (Ziółkowski 1999; Sztompka 1999), the 
altermodernist perspective is more complex and appears to be adaptive. No simple grafting of patterns or models is taking place (Sęk 2015). The horizontal, networked nature of urban activism and its discourses precondition adaptability. This reflects the competences of the activists, who remain open to discussion/dialogue and seek to contextualise their activities and, thereby, mitigate the risk of transplanted ideas and practices.

\section{Can Polish Urban Social Movements Succeed? Conclusions Posed as Questions}

Even though these processes are taking place now, in statu nascendi, a key question must be posed about their potential effectiveness or the efficiency of the movements' agency. To pose the question openly: can urban movements succeed? Or otherwise, how does one define success for social urban movements? At least two perspectives are available here.

In spite of declarations of support for RTTC movements taking part in elections to local government, many activists stop in the antechamber of institutionalized politics, treating the struggle as part of the discourse and never leaving the framework of the public sphere (Mergler 2013a). They continue shaping ideas, translating and constructing alternative modernization, and sometimes presenting readymade solutions for the city's problems from the position of social experts, assisting both urban politicians and officials.

Some activists do cross the Rubicon. While urban movements are not primarily power-oriented, they demand and take responsibility for joint control, sharing power in a few regional governments throughout Poland, both on city and district councils and-increasingly-as experts or officials. In the latter case, Merrifield's (2014, pp. 121-122) 'double agent' logic is brought to light. The grafting of urban ideas happens through personal participation in the system, a particular iteration of the former soixante-huitards program, the 'long march through institutions'.

This part of activist history, which-carrying the potential threat of oligarchization-always arouses controversy, is still being written by Polish RTTC movements. The most recent local elections brought them moderate success. Representatives of urban movements won seats on city (Gorzów, Poznań, Toruń) and district councils (Warsaw). In Gorzów, an urban movement candidate was elected mayor, while in Poznań the successful candidate for mayor was a figure sympathetic to urban activism and a former member of an influential urban NGO, who named as his deputy mayor for transport issues Maciej Wudarski, an activist tied to another important urban NGO.

The overall tally in this transition, however, has not been so one-sided. As council member activists have taken on new roles, they have quickly realized that-despite acquiring 'harder' instruments for affecting change-the day-to-day struggle to create dream cities is more a matter of enacting systematic, consistent and evolutionary policies concerning small matters than of seeking opportunities to bring about a rapid/sudden and profound 'urban revolution'. Relations with 'urban presidents' are even more complicated. During the most recent, Fifth Congress of Urban Movements, a special resolution was prepared withdrawing support for Jacek Wójcicki, the President of Gorzów, who-in the opinion of the Congress-has implemented policies openly in conflict with their 'Urban Theses' and the postulates of the local urban movements. The cooperation between Jacek Jaśkowiak, the President of Poznań, and local activists has also not been unproblematic and has been critically assessed by some local communities. Despite the doubts they have expressed, representatives of a large number of urban movement groups have agreed to take part in the upcoming local elections. However, a separate study should be devoted to this aspect of the functioning of Polish urban movements.

For both cases, however, the effect of changes in urban praxis and imaginarium is key. The more the results of volunteer activist work are 'consumed' by local governments, stakeholders and decisionmakers, the better for cities. Activists themselves stress this relation: the more altermodernist imaginations and practices are intercepted, but not instrumentalized by local governments, the bigger the success for the movements.

Acknowledgements Research were carried out in 2015-2017 with financial support from Adam Mickiewicz University's Institute of Sociology

Funding This study was funded in whole by Adam Mickiewicz University's Institute of Sociology. No other funding sources were involved in the research process.

\section{Compliance with Ethical Standards}

Conflict of interest Author has received no research grants; no conflict of interest exists.

Open Access This article is distributed under the terms of the Creative Commons Attribution 4.0 International License (http://crea tivecommons.org/licenses/by/4.0/), which permits unrestricted use, distribution, and reproduction in any medium, provided you give appropriate credit to the original author(s) and the source, provide a link to the Creative Commons license, and indicate if changes were made.

\section{References}

Angrosino, M. (2007). Doing ethnographic and observational research. Thousand Oaks: SAGE.

Aslund, A. (2007). How capitalism was built. The transformation of central and eastern Europe, Russia, and Central Asia. Cambridge: Cambridge University Press. 
Audycka-Zandberg, B. (2013). Warunki i strategie mobilizacji najemców lokali mieszkalnych $w$ stowarzyszeniach lokatorskich [unpublished doctoral thesis, University of Warsaw]

Bakker, K. (2007). The 'Commons' versus the 'Commodity': Alterglobalization, anti-privatization and the human right to water in the global south. Antipode, 39(3), 430-455.

Baranowski, M. (2010-2011). The property rights theory approach from a socio-economic viewpoint. Studia Historiae Oeconomicae, 28(29), 3-16

Bielski, P. (2010). Grupa Pewnych Osób, czyli swobodna sieć twórczych buntowników. Czas Kultury, 4(157), 50-57.

Billert, A. (2012). Niemiecka polityka rewitalizacyjna. Miasta, 1(1), $68-71$.

Bogucka, M., \& Samsonowicz, H. (1986). Dzieje miast i mieszczaństwa w Polsce przedrozbiorowej. Ossolińskich: Zakład Narodowy im.

Bollier, D. (2014). Think like a commoner. A short introduscion to the life of the commons. Gabriola Island: New Society Publishers.

Brenner, N. (Ed.). (2013). Implosions/explosions: towards a study of planetary urbanization. Berlin: Jovis.

Brenner, N., Marcuse, P., \& Mayer, M. (2009). Cities for people, not for profits. Introduction. City: Analysis of Urban Trends, Culture, Theory, Policy, Action, 13(2-3), 176-184.

Brzozowska-Brywczyńska, M. (2013). Plac zabaw: Krótka instrukcja obsługi. Miasta, 1(2), 66-68.

Buczek, G. (2013). Dla dobra wspólnego: Karta Przestrzeni Publicznej. Miasta, 1(2), 53-57.

Bukowiecki, Ł., Obarska, M., \& Stańczyk, X. (Eds.). (2014). Miasto na żadanie. Aktywizm, polityki miejskie, doświadczenia, Wydawnictwa Uniwersytetu Warszawskiego, Warszawa.

Burawoy, M. (2004). For public sociology. 2004 Presidential Address. http://burawoy.berkeley.edu/Public\%20Sociology,\% 20Live/Burawoy.pdf. Accessed 4 April 2018

Castells, M. (1977). The urban question. A marxist approach. London: Edward Arnold.

Castells, M. (1983). The city and the grassroots: A cross-cultural theory of urban social movements. London: Edward Arnold.

Castells, M. (2010). The power of identity. Oxford: Wiley Blackwell.

Ciszewski, P., \& Nowak, R. (2016). Wszystkich nas nie spalicie. Warszawa: Trzecia Strona.

Corr, A. (1999). No trespassing: Squatting, rent strikes and land struggles worldwide. Cambridge: South End Press.

Czapka, B. (2010). Budżet partycypacyjny: Pieniądze i ideologie. Przeglad Anarchistyczny, 11, 5-18.

Domaradzka, A. (2015). Changing the rules of the game: Impact of the urban movement on public administration practices. In M. Freise, F. Paulsen, \& A. Walter (Eds.), Civil society and innovative public administration. Baden Baden: Nomos.

Domaradzka, A., \& Wijkström, F. (2016). Game of the city renegotiated: The polish urban re-generation movement as an emerging actor of a strategic action field, Polish Sociological Review, 3 (195)

Dorda, K. (2015). Sharing City. Miasta, 1(9), 30-32.

Dunn, E. (2004). Privatizing Poland: Baby food, big business, and the remaking of labor. Ithaca: Cornell University Press.

Enright, T., \& Rossi, U. (2017). Ambivalence of the urban commons. In A. Jonas, B. Miller, K. Ward, \& D. Wilson (Eds.), The routledge handbook on spaces of urban politics. Oxford: Routledge.

Erbel, J. (2016). Strategia dla zdrowego miasta. Miasta, 3(15), 40-43.

Erbel, J., \& Ratajczak, M. (2013). Prawo do dobra wspólnego. Miasta, 1(2), 38-43.

Esping-Andersen, G. (1990). The three worlds of welfare capitalism. Oxford: Polity Press.
Fainstein, N. I., \& Fainstein, S. S. (1974). Urban political movements: The search for power by minority groups in American Cities. Englewood Cliffs: Prentice-Hall.

Fischer, W. F., \& Ponniah, T. (Eds.). (2003). Another world is possible. Popular alternatives to globalization at the world social forum. New York: Zed Books.

Friedman, M. (1982). Capitalism and freedom. Chicago: University of Chicago Press.

Gehl, J. (2010). Cities for people. Washington: Island Press.

Gemzoe, L., \& Żakowska, M. (2013). Życie publiczne. Miasta, 2(4), $13-16$.

George, S. (2004). Another World is Possible If... New York: Verso

Gerwin, M. (2013a). Budżet obywatelski: Od nowych chodników do lokalnej społeczności. Miasta, 1(2), 30-34.

Gerwin, M. (2013b). Z samochodem w tle. Miasta, 2(4), 25-29.

Gerwin, M. (2015). Panele obywatelskie. Miasta, 1(9), 22-25.

Giddens, A. (1994). Beyond left and right: The future of radical politics. Cambridge: Polity Press.

Górski, R. (2007). Bez państwa. Demokracja uczestniczaca w działaniu. ha!art, Kraków

Gorzelak, G. (2013). Długie trwanie a współczesność. Miasta, $3-4(5-6), 40-43$.

Grabowska, M. (2004). Podziat poskomunistyczny. Spoteczne podstawy polityki w Polsce po 1989 roku. Warszawa: Wydawnictwo Naukowe Scholar.

Graham, W. (2016). Dream cities. Seven urban ideas that shape the world. New York: Harper Perennial.

Grosse, T. G. (2010). Europeizacja In W. Morawski (wd.). Modernizacja Polski. Struktury - agencje - instytucje, Warszawa: Wydawnictwa Akademickie i Profesjonalne, pp. 289-316

Haratyk, K., \& Wnęk, D. (2012). Prawo lokatorskie w działaniu. Miasta, 1(1), 29-32.

Hardt, M., \& Negri, A. (2009). Commonwealth. Cambridge: The Belknap Press of Harvard University Press.

Hardy, J. (2009). Poland's new capitalism. London: Pluto Press.

Harvey, D. (2003). The new imperialism. Oxford: Oxford University Press.

Harvey, D. (2012). Rebel cities. From the right to the city to urban revolution. London: Verso.

Hebanowski, W. (2015). Miasta otwarte. Miasta, 3(11), 52-55.

Jacobs, J. (1992). The death and life of great american cities. New York: Vintage Books.

Jacobsson K. (2014). Entrepreneurial Poland. On Civic Privatism in polish civil society organizations [3rd draft]. http://www. detcivilasamhallet.se/pages/dokument/jacobsson_entrepreneur ial_poland.pdf. Accessed 26 April 2017

Jacobsson, K. (2016). Introduction: The Development of Urban Movements in Central and Eastern Europe. In K. Jacobsson (Ed.), Urban grassroots movement in Central and Eastern Europe. New York: Routledge.

Janowski, M. (2004). Polish liberal thought before 1918. Budapest: Central European University Press.

Jaworski, P. (2016). Miejskie prototypowanie. Miasta, 2(14), 50-53.

Kacperski, W., \& Kusiak, J. (2012). Kiosks with vodka and democracy: Civic cafes between new urban movements and old social divisions. In M. Grubbauer \& J. Kusiak (Eds.), Chasing warsaw. Socio-material dynamics of urban change since 1990 (pp. 213-238). Frankfurt/M: Campus Verlag.

Kajdanek, K. (2012). Suburbanizacja po polsku. Kraków: NOMOS.

Kaniowski, A. M. (2003). Polska sfera nie-publiczna. Krytyka Polityczna, 3, 90-96.

Kolasa-Nowak, A. (2010). Zmiana systemowa $w$ Polsce $w$ interpretacjach socjologicznych. Lublin: Wydawnictwo Uniwersytetu Marii Skłodowskiej-Curie. 
Kostka, J., \& Czarnota, K. (2017). Modes of knowledge production in the study of radical urban movements. Interface: A Journal for and About Social Movements, 9(1)

Kowalewski, M. (2016). Protest miejski. Przestrzenie, tożsamości $i$ praktyki niezadowolonych obywateli miast, Zakład Wydawniczy NOMOS, Kraków

Kowalik, T. (2010-2011). Property rights and social justice. Studia Historiae Oeconomicae, 28-29, 69-100

Kowalik, T. (2012a). From solidarity to sellout. The restoration of capitalism in Poland. New York: Monthly Review Press.

Kowalik, T. (2012b). www.polskatransformacja.pl, Warszawskie Wydawnictwo Literackie MUZA SA, Warszawa

Krier, L. (2009). The architecture of community. Washington: Island Press.

Kubicki, P. (2011). Nowi mieszczanie $w$ nowej Polsce. Raport $z$ badań. Warszawa: Instytut Obywatelski.

Kubicki, P. (2016a). Polskie ruchy miejskie: Polityczne czy kulturowe? Przeglad Socjologiczny, 65(1), 65-79.

Kubicki, P. (2016b). Wynajdywanie miejskości. Polska kwestia miejska z perspektywy dtugiego trwania. Kraków: Zakład Wydawniczy NOMOS

Kvale, S. (2007). Doing interviews. Thousand Oaks: SAGE.

Laclau, E. (2007). Emancipation(s). New York: Verso.

Leder, A. (2014). Prześniona rewolucja. Ćwiczenie z logiki historycznej. Warszawa: Wydawnictwo Krytyki Politycznej.

Linebaugh, P. (2014). Stop Thief! The commons enclosures and resistance. Oakland: PM Press.

Lipiński, A. (2016). Strategie 'komunizacji' przeciwnika politycznego. Obraz środowiska Unii Wolności w dyskursie polskiej prawicy. Przeglad Politologiczny, 3, 93-107.

Litorowicz, A. (2014). Nowe rozwiązania miejskie. Miasta, 2(8), $83-85$.

Lowe, S. (1986). Urban social movements. The city after castells. London: Macmillan.

Łuczak, K. (2015). Ruchy miejskie w poszukiwaniu wartości i idei kluczowych dla rozwoju miast. Acta Sociologica Lodziensis: Folia Sociologica, 54, 159-175.

Manifest nowej polityki mieszkaniowej. (2012). Miasta, 1 (1), 10

Marcuse, P. (2009). From critical urban theory to the right to the city. City: Analysis of Urban Trends, Culture, Theory, Policy, Action, 13(2-3), 185-196.

Martela, B., \& Wojtaszczyk, P. (2014). Niesforni obywatele: spontaniczne organizowanie się mieszkańców. In A. Przybylska \& A. Giza (Eds.), Partycypacja obywatelska. Od teorii do praktyki spotecznej (pp. 181-193). Warszawa: Wydanictwo Naukowe SCHOLAR.

Marzec, K. (2013). The 1905-1907 revolution in the Kingdom of Poland: Articulation of political subjectivities among workers. Contention: The Multidisciplinary Journal of Social Protest, $1(1), 53-72$

Marzec, W. (2016). Rebelia i reakcja. Rewolucja 1905 roku $i$ plebejskie dośwadczenie polityczne, Wydawnictwo Uniwersytetu Łódzkiego, Towarzystwo Autorów i Wydawców Prac Naukowych UNIVERSITAS, Łódź: Kraków

Matczak, P., Mączka, K., \& Sadło, M. (2015). Budżety obywatelskie w województwie wielkopolskim: stan obecny i perspektywy na przyszłość. Biuletyn Wielkopolskiego Regionalnego Obserwatorium Terytorialnego, $n r, 3,26-31$.

Mayer, M. (2009). The 'Right to the City' in the context of shifting mottos of urban social movements. City: Analysis of Urban Trends, Culture, Theory, Policy, Action, 13(2-3), 362-374.

Mayer, M., Thörn, C., \& Thörn, H. (Eds.). (2016). Urban uprisings: Challenging neoliberal urbanism in Europe. London: Palgrave MacMillan.

Mergler, L. (2011). Konflikty o przestrzeń a stan demokracji miejskiej na wybranych przykładach w Poznaniu In M. Nowak, P.
Pluciński (Eds.), O miejskiej sferze publicznej. Obywatelskośc i konflikty o przestrzeń. ha!art, Kraków, pp. 163-182

Mergler, L. (2013a). Demokracja miejska wobec wyborów. Miasta, 3-4(5-6), 69.

Mergler, L. (2013b). Przyszłość okiem działacza miejskiego. Miasta, 3-4(5-6), 33-35.

Mergler, L., Pobłocki, K., \& Wudarski, M. (2013). Anty-bezradnik przestrzenny: Prawo do miasta $w$ dziataniu. Warszawa: Biblioteka Res Publiki Nowej.

Merrifield, A. (2014). The new urban question. London: Pluto Press.

Molik, W. (2005). Etos Wielkopolan. Antologia tekstów o społeczeństwie Wielkopolski z drugiej połowy XIX $i$ XX wieku, Poznańskie Towarzystwo Przyjaciół Nauk-Uniwersytet im. Adama Mickiewicza - Centrum 'Instytut Wielkopolski'.

Nowak, M., \& Nowosielski, M. (Eds.). (2006). Czy społeczny bezruch? O społeczeństwie obywatelskim $i$ aktywności we wspótczesnej Polsce. Poznań: Wydawnictwo Instytutu Zachodniego.

Nowak, M., \& Pluciński, P. (2011). O miejskiej sferze publicznej. Obywatelskość i konflikty o przestrzeń, ha!art, Kraków

Nozick, R. (2001). Anarchy, state and utopia. Oxford: WileyBlackwell

Ost, D. (2006). The defeat of solidarity: Anger and politics in postcommunist Europe. Ithaca: Cornell University Press.

Ostrom, E. (1990). Governing the commons: The evolution of institutions for collective action. Cambridge: Cambridge University Press.

Pelanosa, G. (2016). Wszyscy jesteśmy pieszymi. Miasta, 2(14), $17-19$.

Penalosa, G., \& Lański, K. (2013). Uliczna demokracja. Miasta, 2(4), $17-20$.

Pickvance, C. (2003). From urban social movements to urban movements: A review and introduction to a symposium on urban movements. International Journal of Urban and Regional Research, 27(1), 102-109.

Piotrowski, G. (2016). Protest tool, social movement or politicized lifestyle? On the nature of squatting in Poland. In I. N. Sava \& G. Pleyers (Eds.), Social Movements in Central and Eastern Europe. A renewal of protests and democracy. Bucureşti: Editura Universităţii din Bucureşti.

Piotrowski, G., \& Lundstedt, M. (2016). Right-to-the-city movements in Poland: A new opening for grassroots mobilizations. In I. N. Sava \& G. Pleyers (Eds.), Social movements in central and Eastern Europe. A renewal of protests and democracy. Bucureşti: Editura Universităţii din Bucureşti.

Piotrowski, G., \& Polanska, D. V. (2016). Radical urban movements in Poland: The case of squatting. Miscellanea Anthropologica et Sociologica, 17(1), 53-69.

Pluciński, P. (2013). Miejskie (r)ewolucje. Radykalizm retoryki a praktyka reformy. Praktyka teoretyczna, 3(9), 133-157.

Pluciński, P. (2014). Miasto to nie firma. Dylematy i tożsamość polityczna miejskich ruchów społecznych we współczesnej Polsce. Przeglad Socjologiczny, 63(1), 137-170.

Pluciński, P. (2015). Im lepiej, tym gorzej albo widmo kryzysu miejskich ruchów społecznych. Ruch Prawniczy, Ekonomiczny $i$ Socjologiczny, 77(1), 409-423.

Pluciński, P. (2016). Jaka demokracja miejska? Przypadek Ruchu Społeczeństwa Alternatywnego. Nowa Krytyka, 36, 133-150.

Pobłocki, K. (2011). Prawo do miasta i ruralizacja świadomości we współczesnej Polsce. In M. Nowak \& P. Pluciński (Eds.), $O$ miejskiej sferze publicznej. Obywatelskość i konflikty o przestrzeń (pp. 129-146). Kraków: Ha!art.

Pobłocki, K. (2014). Gentryfikacja, własność i polski kapitalizm polityczny, Politeja. Pismo Wydziatu Studiów Międzynarodowych $i$ Politycznych UJ, 27, 157-177. 
Podemski, K. (Ed.). (2009). Spoteczeństwa Europy ŚrodkowoWschodniej: Projekt Eurequal. Poznań: Wydawnictwo Naukowe UAM.

Polakowski, M. (2016). Samochodom dziękujemy. Miasta, 2(14), $38-41$.

Polanska, D. (2016a). Alliance building and brokerage in contentious politics: The case of the polish tenants' movement. In K. Jacobsson (Ed.), Urban grassroots movement in Central and Eastern Europe, New York: Routledge

Polanska, D. V. (2016b). Neoliberal post-socialist urban transformation and the emergence of urban social movements in Poland. In M. Mayer, C. Thörn, \& H. Thörn (Eds.), Urban uprisings: Challenging neoliberal urbanism in Europe (pp. 311-334). New York: Palgrave Macmillan.

Polanska, D. V., \& Piotrowski, G. (2015). The transformative power of cooperation between social movements: The case of squatting and tenants' movements in Poland. City: Analysis of Urban Trends, Culture, Theory, Policy, Action, 19(2-3), 208-230.

Polyak, L. (2013). Recykling miasta: mapowanie i korzystanie z pustostanów. Miasta, 2(4), 75-77.

Praczyk, M. (2017). Poznań w działaniu: Społeczne inicjatywy dawniej i dziś. Poznań: Fundacja Czasu Kultury.

Prykowski, Ł. (2013). Łódź obywatelska. Przygotowania do budżetu obywatelskiego na 2014r. Miasta, 1(2), 36-37.

Ptaśnik, J. (1949). Miasta $i$ mieszczaństwo $w$ dawnej Polsce. Warszawa: Państwowy Instytut Wydawniczy.

Puchalski, Ł. (2013). Miasto pieszych i rowerów. Miasta, 2(4), 59-61.

Raciborski, J. (2011). Obywatelstwo w perspektywie socjologicznej. Warszawa: Wydawnistwo Naukowe PWN.

Rothbard, M. (1978). For a new liberty: The libertarian manifesto. New York: Collier Books.

Rumińska, A. (2013). Stopa zysku, czyli pieszo po mieście. Miasta, 2(4), 33-35.

Sachs, J. (2005). The end of poverty: Economic possibilities for our time. New York: The Penguin Press.

Scerri, A. (2013). The world social forum: another world might be possible. Social Movement Studies, 12(1), 111-120.

Sęk, M. (2015). Kontekst, głupcze! Miasta, 1(9), 100-103.

Sevilla-Buitrago, A. (2015). Capitalist formations of enclosure: Space and the extinction of the commons. Antipode, 47(4), 829-848.

Smagacz-Poziemska, M. (2015). Czy miasto jest niepotrzebne? (Nowe) przestrzenie życiowe młodych mieszkańców miasta. Kraków: Wydawnictwo Naukowe SCHOLAR.

Śmiechowski, K. (2014). Searching for the better city. An urban discourse during the Revolution of 1905 in the Kingdom of Poland. Praktyka Teoretyczna, 4, 71-96.

Śmiechowski, K., \& Marzec, W. (2016). Pathogenesis of the polish public sphere. The intelligentsia and popular unrestduring and after the 1905 Revolution. Polish Sociological Review, 4(196), $437-457$.

Smith, N. (2010). Uneven development: nature, capital and the production of space. London: Verso.
Soja, E. W. (2010). Seeking Spatial Justice. Minneapolis: University of Minnesota Press.

Sowa, J. (2011). Fantomowe ciało króla. Peryferyjne zmagania z nowoczesna forma. Kraków: Towarzystwo Autorów i Wydawców Prac Naukowych UNIVERSITAS.

Sowada, T., \& Kotus, J. (2015). Rola stowarzyszeń lokalnych w procesie partycypacji spotecznej $w$ zarzadzaniu miastem. Przyktad Poznania. Poznań: Bogucki - Wydawnictwo Naukowe.

Śpiewak, J. (2015). Ruchy miejskie, czyli potyczki o władzę w polu inteligencji $\mathrm{w}$ kontekście przemian systemu neoliberalnego. Kultura Wspótczesna: Teoria, interpretacje, praktyka, 1, 80-91.

Springer, F. (2013). Wanna z kolumnada: Reportaze o polskiej przestrzeni. Wołowiec: Czarne.

Świderski, M. (2016). Katalońska ewolucja. Miasta, 2(14), 74-76.

Szczerba, M. (2013). Seniorzy w samorządach. Miasta, 3-4(5-6), 48-49.

Sztompka, P. (1993). Civilizational incompetence: The trap of postcommunist societies. Zeitschrift Für Soziologie, 22(2), 85-95.

Sztompka, P. (Ed.). (1999). Imponderabilia wielkiej zmiany. Mentalność, wartości $i$ więzi społeczne czasów transformacji. Warszawa: Wydawnictwo Naukowe PWN.

Tittenbrun, J. (1993). The collapse of 'Real Socialism' in Poland. London: Janus Publishing Company.

Tittenbrun, J. (1996). Private versus public enterprise. In Search of the Economic Rationale for Privatisation: Janus Publishing Company, London.

Tittenbrun, J. (2014). Concepts of capital. The commodification of social life. New Brunswick: Transaction Publishers.

Urbański, J. (2011). Fabryka versus agora. Szkic z ekonomii politycznej miasta. In M. Nowak, P. Pluciński (Eds.), O miejskiej sferze publicznej. Obywatelskość i konflikty o przestrzeń, ha!art, Kraków, pp. 239-257

Urbański, J. (2012). W kwestii mieszkaniowej raz jeszcze. Miasta, $1(1), 20-24$.

Wallerstein, I. (2004). World-systems analysis: An introduction. Durham: Duke University Press.

Weihsmann, H. (2001). Das rote Wien. Sozialdemokratische Architektur und Kommunalpolitik 1919-1934. Wien: Promedia Verlag.

Witkowski, P. (2013). Kaletnik, witrażysta, i koronkarz, czyli rewitalizacja Nadodrza. Miasta, 1(2), 62-65.

Zboralski, Ł. (2016). Miejscy aktywiści chcą nas zabić, Do Rzeczy, 09.08.2016, https://dorzeczy.pl/10233/Miejscy-aktywisci-chcanas-zabic.html. Accessed 26 April 2017

Zerka, P. (2013). Bogota: Laboratorium miejskich przemian. Miasta, $1(2), 46-49$.

Ziółkowski, M. (1999). O imitacyjnej modernizacji społeczeństwa polskiego. In P. Sztompka (Ed.), Imponderabilia wielkiej zmiany. Mentalność, wartości $i$ więzi społeczne czasów transformacji. Warszawa-Kraków: Wydawnictwo Naukowe PWN. 